\title{
THE REPLICATIVE CMG HELICASE: THE IDEAL TARGET FOR CANCER THERAPY
}

\author{
W. HENDERSON, K. NYMAN, M. STONEY, S. I. BORYSOV \\ College of Arts and Sciences, Saint Leo University, St. Leo, Florida, USA; \\ 凶e-mail: Sergiy.Borysov@saintleo.edu
}

Received: 31 May 2020; Accepted: 13 November 2020

This review focuses on Cdc45-Mcm2-7-GINS (CMG) helicase which is a key component of the cellular replication machinery and a new promising target for cancer therapy. In normal cells, only a small proportion of helicases becomes activated through the step-wise acquisition of all necessary subunits during genome replication and a large quantity of reserve dormant helicases exist to replace inhibited helicases, making the normal cells insensitive to helicase inhibition. The collective evidence in the field shows that in contrast to normal cells, cancer cells have a significantly reduced pool of dormant helicases and might be vulnerable to $C M G$ helicase inhibitors. Functional studies confirm that targeted inhibition of CMG helicase could be a strong and specific anticancer approach that ensures efficiency against a broad spectrum of cancers and limited adverse effects on normal cells. We anticipate that therapeutics that inhibit CMG helicase can be used not only as a stand-alone therapy but also as effective chemosensitizers in combination with other drugs, thus increasing their clinical application.

Ke y wo rd s: cancer cells, replicative CMG helicase, MCM, helicase backup, helicase inhibitors.

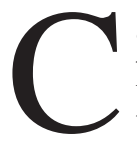

ancer is the second leading cause of death having profound impact on humanity and the economy. There is a need to combat cancer with novel therapeutics that effectively eradicate cancer cells, while spare normal healthy cells. This review focuses on the CMG helicase as a new promising target for such treatment. The replicative CMG helicase is a key component of the cellular replication machinery. Active CMG helicase is comprised of 11 protein subunits, assembly of which occurs in a controlled stepwise manner. During replication of the genome, only a small proportion of available helicases become activated through the acquisition of all necessary subunits. Incomplete helicases remain dormant. Collective evidence suggests that normal cells possess a reserve of dormant helicases that can be activated to replace stalled helicases, thereby ensuring continuation of DNA replication. Contrary to normal cells, cancer cells' reserves of dormant helicases are dramatically reduced. Because of this, cancerous cells might be particularly sensitive to agents that affect helicase activity. We speculate that targeting CMG helicase represents a strong and specific anticancer approach that will have efficacy against a broad spectrum of tumors with limited or no adverse effect on normal cells.

\section{Cancer: the Present State}

Cancer is the second leading cause of death worldwide. In 2018, it was estimated that over 9.6 million people succumbed to this debilitating disease $[1,2]$. The worldwide cancer incidence rates for 2018 are alarmingly high. Approximately 17 million new cases were documented for 2018 year alone [2]. In 2018, the Eastern Asian region reported the highest number of new cancer cases and cancer mortality rates, which were 5.6 million new cases, and 3.4 million deaths. Central and Eastern Europe and North America had incidence rates of 1.2 million and 2.4 million new cases, respectively, and mortality rates of 700,000 for both [3]. These raising cancer incidence and mortality rates have a considerable burden on economies and healthcare sectors. Indeed, the sum of the global economic burdens of cancer in 2010 was estimated to be over $\$ 1$ trillion [4].

(C) 2020 Henderson W. et al. This is an open-access article distributed under the terms of the Creative Commons Attribution License, which permits unrestricted use, distribution, and reproduction in any medium, provided the original author and source are credited. 
With cancer having far-reaching impacts on humanity and economy, the further advancement of cancer treatment is imperative. As of today, the conventional forms of cancer therapy include surgery, radiation, and chemotherapy, with immunotherapy quickly gaining a stand of a prominent treatment option [8-10]. Despite a significant improvement of available cancer treatment options, there is still a need for novel cancer therapies that eliminate cancerous cells, without interfering with non-cancerous cells. The purpose of this review is to consider the replicative CMG helicase as a target of a novel cancer therapy that exploits natural vulnerability of cancer cells.

\section{CMG Helicase: Overview}

DNA replication in the context of the cell cycle. DNA replication is a crucial step of the process of cell division. Initiation of DNA replication marks an irreversible commitment to the cell cycle, ultimate goal of which is to produce two daughter cells with complete and identical sets of chromosomes. DNA replication is initiated at numerous origins of replication spread throughout the cellular genome. Each origin is marked by a multi-protein complex, the origin recognition complex (ORC). Importantly, each origin becomes active only once per cell cycle to prevent re-replication of parts of the genome [11].

Progression to $\mathrm{M}$ phase with subsequent division of the cell occur only when DNA replication is accomplished. If replication of the entire genome cannot be achieved, the affected cell will not divide, but succumb to apoptosis. Indeed, targeting DNA replication is a staple of most cancer chemotherapies [12].

Components of CMG helicase and their functions. Helicases are the enzymes that utilize the energy of ATP hydrolysis to separate doublestranded DNA into single-stranded DNA. Helicases play pivotal roles in several key molecular processes related to the maintenance and metabolism of DNA, including DNA replication, DNA repair, DNA recombination, as well as telomere maintenance [13]. One particular class of helicases, the CMG helicase, is the focus of this review. The CMG helicases have an essential role in DNA replication being the only replicative helicases in all eukaryotes [13].

MCMs. The core of the CMG helicase is represented by a ring-like structures formed by six MCM proteins, specifically, MCM2, MCM3, MCM4, MCM5, MCM6, and MCM7 [13]. Originally iden- tified as proteins essential to maintaining extrachromosomal DNA in Saccharomyces cerevisiae, MCMs is a highly conserved family of proteins that is necessary for initiation and elongation of DNA replication in eukaryotes [14].

This protein family is a subtype of the AAA+ ATP-ase family [15]. ATP-hydrolysis and unwinding of DNA by the MCM ring relays on a cooperation between adjacent subunits. The AAA+ ATPase domain of each MCM associates with an arginine finger of the neighboring MCM subunit [16]. The hydrolysis of ATP induces conformational changes of internal loops protruded into the cavity of the MCM ring that plays a role in helicase translocation along DNA [17]. Importantly, the MCM ring alone cannot act as an active helicase, as it requires the binding of additional subunits, Cdc45 and GINS [18,19].

Cdc45. The MCM ring becomes an active helicase through association with Cdc45 and GINS, forming the CMG complex $[18,19]$. The binding of Cdc45 acts as a tight regulatory point for the CMA activation and initiation of DNA replication. This association is facilitated by cyclin-dependent kinases and Dbf4-dependent kinase [20], and mediated by a chaperon-like function of Treslin [21].

Cdc45 is thought to act as a rate limiting factor in the formation of active CMG helicases, as the levels of this protein are low in comparison to other subunits [22]. Indeed, the over-expression of Cdc45 correlates with an increase in the number of activated replication foci and greater proliferation, reinforcing the idea that binding of Cdc45 is a rate limiting step in cell proliferation [22, 23].

GINS. The GINS complex is the second component required to bind to the MCM ring to form the active CMG replicative helicase. In eukaryotes, the GINS complex consists of Sld5, Psf1, Psf2, and Psf3 subunits [24]. Crystallization studies showed that the GINS complex forms a trapezoidal tetramer structure with a narrow cavity in the center [25-27].

Chromatin-association of the GINS complex is controlled by cyclin-dependent kinases [24] and executed by loading proteins Sld3 and Dpb11 [28]. As GINS does not have its own enzymatic activity, its role in the CMG helicase and the replisome as a whole is still unclear. Proposed functions for the GINS complex varies. GINS may be an integrative structural component of the replisome that stabilizes helicase or links helicase to other components of the replisome, such as DNA polymerase [24]. As GINS is known for its affinity toward single stranded DNA 
[29], it also was speculated that it may represent the "cutting blade" of the helicase that physically separates the DNA double helix [30].

CMG Complex. After the joining of the MCM ring with Cdc45 and GINS, the active CMG helicase is formed. It is thought that the CMG complex is conserved not only among eukaryotes but also among archaea due to identification of MCM, GINS, and Cdc45 homologs [31].

The mechanism of DNA unwinding by the CMG helicase is still debatable. According to a "lagging-strand DNA extrusion model”, the MCM ring of the helicase encircles only the leading strand of DNA, while the lagging strand is being extruded during the progression of the helicase [32]. In support of this model, it was shown that the central channel of the MCM ring is obstructed by an internal protrusion from the MCM5 subunit, reducing its diameter to a size that cannot accommodate double stranded DNA [33].

An "internal unwinding model" claims that during progression of the CMG helicase, the double stranded DNA enters the helicase and the unwinding occurs internally in the central cavity [34]. At least partially, this model is supported by Cryo electronic microscopy images that show double stranded DNA within the central channel of CMG helicase [35]. According to this model, the lagging chain could be excluded through a side opening between MCM2 and MCM6 subunits, or disgorged back through the central channel [34]. Recent elaborations of this model showed that the frontal $\mathrm{N}$-terminal side of the CMG helicase can be subdivided into two structural and functional sub-units: the zinc finger ring that allows double-stranded DNA in and the oligosaccharide/oligonucleotide-binding ring that diverts lagging single-stranded DNA sideway through a diversion tunnel formed by hairpin-loops of MCM3, 4, 6, and 7 [36].

Assembly of CMG helicase. Chromatin loading and assembly of CMG helicases are central for the initiation of DNA replication. It is a complex process that involves three main steps (Fig. 1). First, the heterohexameric origin-recognition complex ORC binds to DNA to mark future sites of replication initiation [11]. Throughout the G1 phase of the cell cycle, the ORC complexes engage with two accessory proteins Cdc6 and Cdt1, both of which are required for recruitment of the MCM ring to the chromatin [37]. Loading of the MCM ring into chromatin is an energy-dependent process that requires ATP hydrolysis. Indeed, proteins comprising the ORC complex contain classical AAA+ domains, and two of them, Orc2 and Orc5, are shown to bind ATP [38]. Similar to these ORC subunits, Cdc6 also contains an AAA+ domain [39]. It is suggested that ATP hydrolysis by ORC, Cdc6, and the MCM ring itself is involved in the loading of helicase to chromatin [40].

Loading of helicase to replication origins requires opening and closing of the MCM ring for DNA to enter the central channel of the complex. Structural and functional studies support the model in which the junction between MCM2 and MCM5 subunits represents a closing/opening gate of the MCM ring [41,42]. It is proposed that binding of Cdt1 opens the Mcm2/5 gate, while Cdc6-mediated ATP hydrolysis dislodges Cdt1 from MCM, resulting in its closure [43]. Once loaded, MCM2-7 forms "head-to-head" double-hexameric pairs encircling double stranded DNA [44] (Fig. 1).

To prevent re-replication of DNA, MCM loading onto chromatin is limited only to G1 phase. This rigid control of loading is called "licensing". It functions - at least partially - through cyclindepended kinases, phosphorylation by which leads to destruction of the MCM-loading protein Cdc6, whereby ensuring that the loading happens only once per cell cycle [42].

By the end of G1, the number of MCM rings bound to DNA reaches its maximum level, which exceeds the amount required for a complete genome replication by several folds [23]. These loaded MCM rings do not contain Cdc45 and GINS subunits necessary to establish active helicases, and thus, are considered dormant. In fact, the majority of licensed MCM rings remain dormant and unused, and are utilized only as backups if nearby active helicase are disabled. This ensures continuation of DNA replication and acts as a safeguard against under-replication of DNA [45, 46].

At the G1/S traverse and during the $\mathrm{S}$ phase, CDC7 and CDK kinases phosphorylate a small percentage of dormant MCMs to facilitate their association with GINS and Cdc45 and formation of active CMG helicases $[47,48]$. By the end of the S phase, the remainder of DNA-bound dormant MCM helicases is most likely removed by progressing replication forks. Upon the termination of replication, active CMG helicase complexes are unloaded from DNA at converging replication forks [49]. This could be regulated by a Cdc48-dependent poly-ubiquitylation of MCM7, which was revealed in recent studies of Xenopus extracts and budding yeast [50, 51]. 


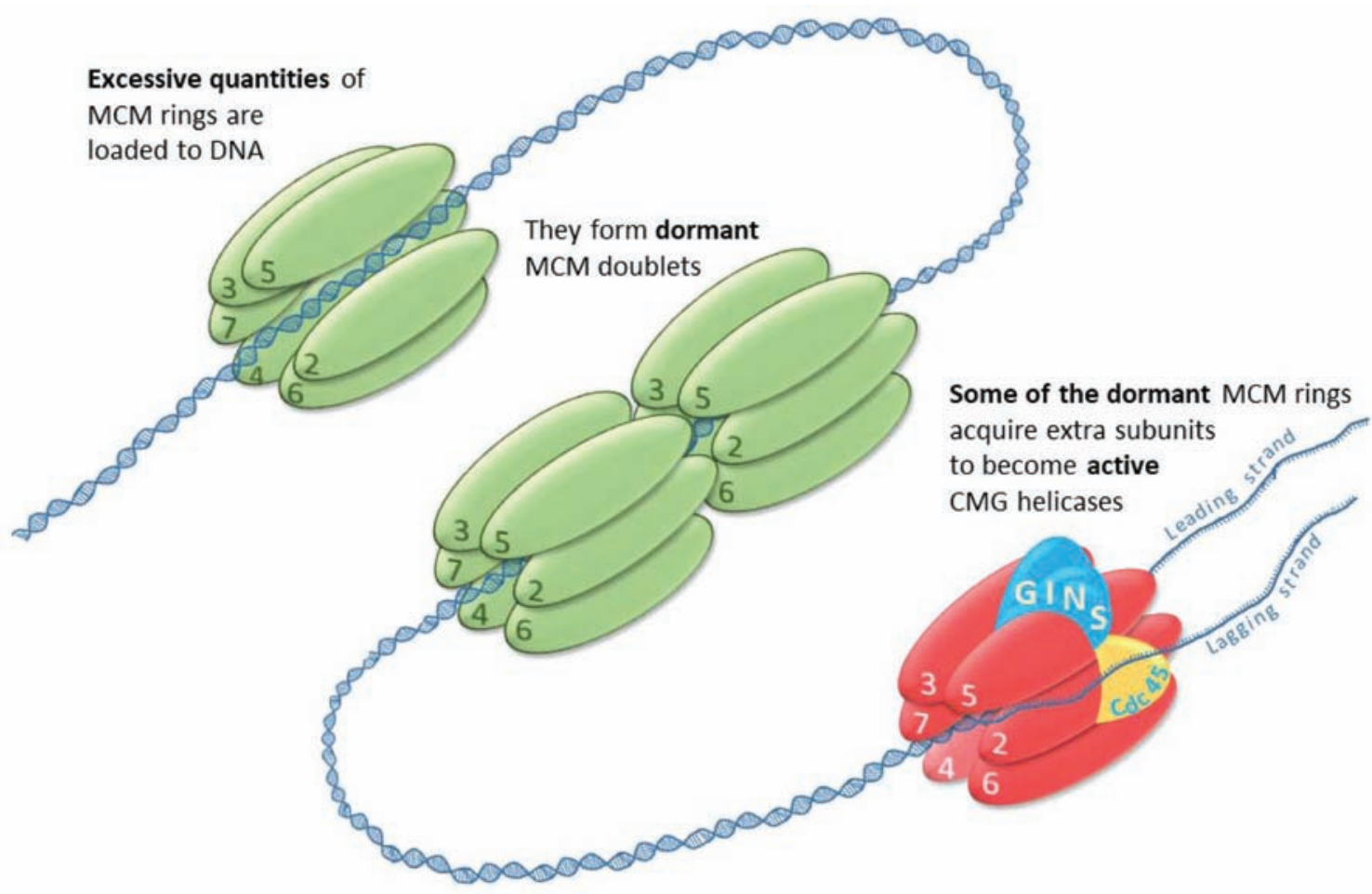

Fig. 1. Step-wise assembly of active CMG complex

\section{Targeting CMG helicase}

Evidence for helicase backup. It is estimated that somatic cells load 4 to 10 MCM hexamers per each replicon $[24,53,54]$. Assuming that only two of MCM rings are actively utilized during DNA replication, the rest of the loaded MCM rings represents a several fold excess of dormant helicases [24,53,54].

Several functional studies that utilized tissue culture cells or the cell-free system of Xenopus laevis egg extracts confirmed the presence of a backup of dormant helicases that can be activated to compensate for loss of helicase activity in stalled replicative forks. In one such study, the amounts of chromatin-loaded MCMs were artificially manipulated in Xenopus egg extracts to establish either "maximally licensed" or "minimally licensed" chromatin. "Maximally licensed" extracts had 10-20 MCMs loaded within each replicon (which is normal for embryonic cells that this system represents). "Minimally licensed" extracts were loaded in the presence of geminin, a Cdt1 inhibitor, making the amount of MCMs bound to DNA limited to the minimum required to maintain a normal replication. No significant differences in the kinetics of DNA replication were observed between minimally and maximally licensed extracts [52]. It was concluded that DNA rep- lication can be accomplished by utilization of a small portion of available MCMs [52]. To evaluate a role of the large quantities of unused MCMs, this cell-free model was subjected to replicative stress with low concentrations of different DNA polymerase inhibitors. It was shown that Xenopus egg extracts with maximally loaded MCMs were able to completely rescue DNA replication, whereas extracts with minimally licensed MCMs failed to continue DNA synthesis [52]. This suggests that excess of MCMs provides a reserve of helicases that can be utilized to rescue stalled DNA replication.

Similar conclusions were reached in a different study with human cultured cells. By using siRNA against the MCM5 subunit of the helicase, the authors manipulated with the levels of loaded MCM complexes. It was shown that cells with reduced levels of MCM5 displayed a normal progression through DNA replication. Importantly, when treated with low levels of replication inhibitors, cells with reduced levels of MCM5 failed to maintain normal replication rates. It was concluded that excess of loaded MCMs represents dormant helicases that can be activated under conditions of replicative stress to continue DNA replication and insure entirety of genome replication [53]. 
Another study utilized a similar experimental approach, but targeted different subunits of the helicase, MCM2 and MCM3 [54]. The authors showed that even a very significant (up to $90 \%$ ) reduction in the MCMs levels did not prevent cells from a successful DNA replication and proliferation. However, the cells with reduced MCM levels could not cope with DNA stress induced by replicative inhibitors, such as aphidocolin and hydroxyurea [54].

The role of MCM reserve was also evaluated by utilizing mouse fibroblasts with genetically altered MCM3 that renders instability to the whole MCM rings and, whereby, reducing the levels of chromatin-loaded helicases. Consistently with the model of the MCM dormant reserve, it was shown that when the levels of MCM on chromatin are reduced, cells had more stalled replicative forks and did not complete DNA replication prior to mitosis [55].

\section{Reduction in Helicase Activity as a Therapeutic Approach toward Cancer}

Reduction of MCMs/CMG levels reduces viability of cancer cells, but not normal cells. Research performed in different laboratories points that compared to normal cells, cancer cells possess a reduced reserve of dormant helicases. Without this reserve, cancer cells that subjected to further reduction in the levels of loaded helicases could not complete DNA replication, become arrested in S phase, and undergo apoptosis [56-59]. One such study showed that overexpression of a non-degradable Geminin, an inhibitor of Cdt1, the protein involved in MCM loading, reduced loading of MCMs, and induced a prolonged $S$ phase arrest and apoptosis in osteosarcoma, lung, and breast cancer cell lines. In contrast, IMR90 primary fibroblasts displayed a G1 arrest and no apoptosis under the same conditions. Therefore, normal cells are able to tolerate a reduction in relicensing of helicases, while cancer cells are vulnerable to such perturbation and undergo apoptosis [56].

Another study utilized siRNA knockdown of Cdc6 and ORC2, proteins intimately involved in chromatin loading of MCM rings. It was shown that reduction in the levels of loaded MCMs, caused by depletion of Cdc6 or ORC2, induced the S phase arrest with subsequent recovery in normal human epithelial and fibroblasts cells, while led to aberrant DNA replication and cell death in colorectal, lung, breast, and cervical cancer cells [57]. Consistent results were obtained by a different group that utilized siRNA against ORC1. They showed that the ORC1 deficiency - that must lead to a reduction in helicase loading - induced death of osteosarcoma cancer cells, while it was tolerable by normal fibroblasts [58].

A decrease in DNA replication and viability of lung and bladder cancer cells were also observed after siRNA-mediated reduction in the MCM7 levels. Once again, non-cancer cell lines were not affected [59]. Cumulatively, these results highlight the weakness of helicase function in cancer cells: artificial reduction in helicase loading, which is tolerable by normal cells, leads to a dramatic decrease in survival of cancer cells. This natural phenomenon could be exploited as a novel chemotherapeutic approach in treating cancer (Fig. 2).

Reduction of CMG helicase activity as a chemosensitization approach. A number of reports described above showed that a subliminal reduction in MCM loading becomes lethal to cancerous cells when it is combined with an exposure to low doses of replicative inhibitors [53, 54, 57-59]. These highlighted an additional potential therapeutic application of helicase inhibitors: aside from being used as a stand-alone therapy, they also could be chemosensitizing agents that are combined with other drugs to enhance their tolerance and clinical effect. The main limitation of these studies is that they utilized replicative drugs that are not used in clinic, namely, aphidocolin, a DNA polymerase inhibitor, and hydroxyurea, an inhibitor of ribonucleotide reductase.

By studying compounds approved for cancer therapy, two other reports provided a direct support to the concept of helicase inhibitors as chemosensitizing agents. In one report, the levels of MCM4 and MCM7 in pancreatic and colorectal cancer cells were reduced by siRNA treatment. After that, the cells were treated with low concentrations of chemotherapeutic drugs, gemcitabine or 5-fluorouracil [60]. The authors reported that a $30 \%$ reduction in MCM levels did not affect the cancer cells. However, it increased cytotoxicity of gemcitabine and 5-fluorouracil in comparison to exposure to the drugs alone [60]. Similar results were obtained by a different group that reported a chemisensitization of osteosarcoma cells to camptothecin after a subliminal reduction in the MCM5 levels [53]. Importantly, it was shown that an equivalent siRNA treatment of normal keratinocytes HaCat calls did not induce chemosensitization toward gentamicine [60]. It was proposed that - as cancer cells already possess a reduced reserve of dormant helicases - any 


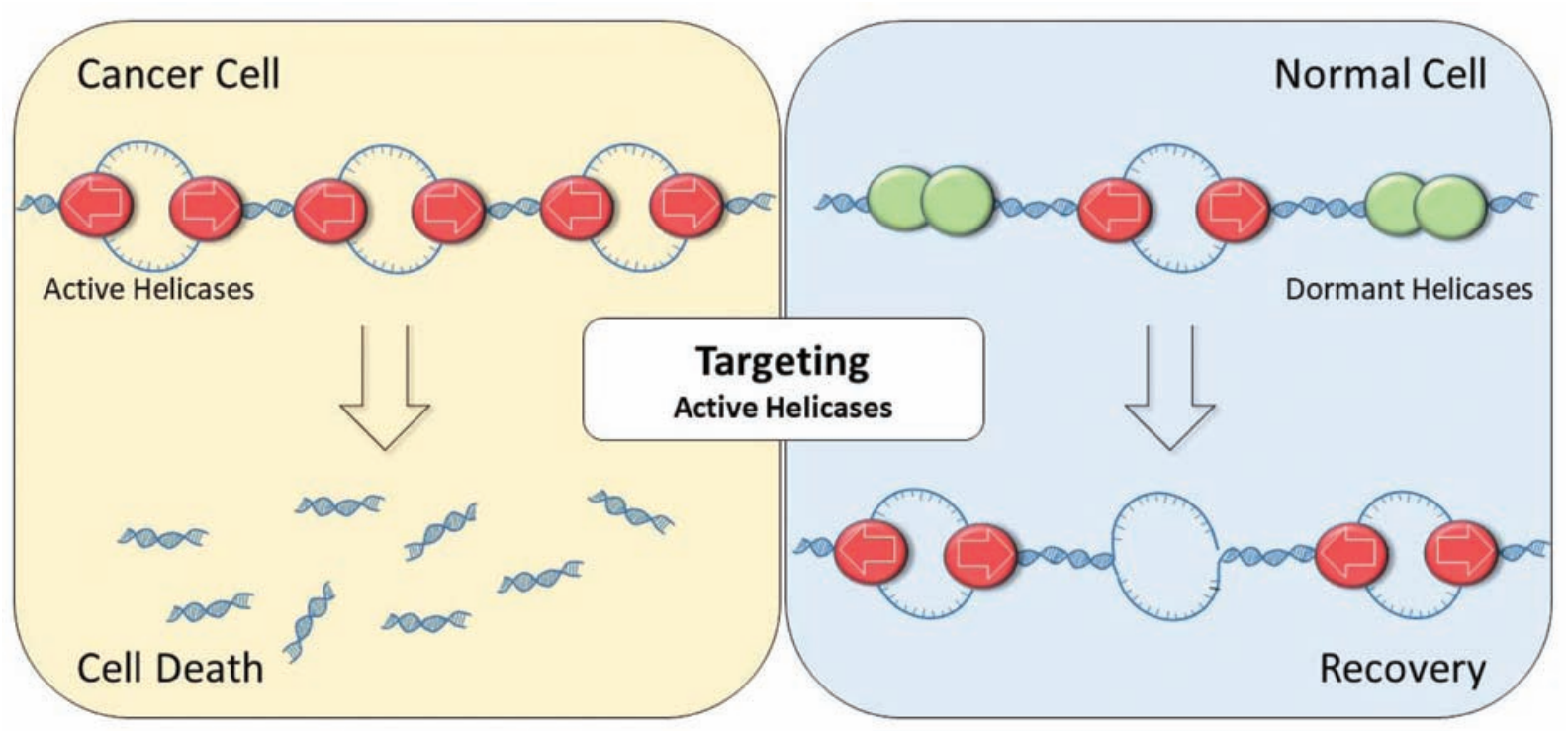

Fig. 2. The lack of dormant helicase reserves predisposes sensitivity of cancer cells to CMG helicase inhibitors

further reduction in helicase loading might severely compromise the capacity of cancer cells to sustain challenged DNA replication. Normal cells - having a much more abundant helicase reserve - can afford its partial depletion and still support DNA replication with remaining helicases.

Small molecules that target MCMs/CMG. As the MCMs are key players in the DNA replication and cellular reproduction, targeting them in cancer treatments became a topic of research interest. The molecules scrutinized for such purposes include Genistein, Trichostatin A, Widdrol, Metformin, BETi, Breviscapine, which downregulate expression of the MCM proteins, as well as Heliquinomycin and Ciprofloxacin, which might directly affect the helicase activity.

Genistein and Trichostatin A, either alone or in conjunction, were shown to lower the levels of expression of all MCM gene family members [61, 62]. As a result, treating cells with these inhibitors halts the replication process. It was proposed that Genistein and Trichostatin A affect expression of MCM subunits indirectly by downregulating signaling pathways, such as JNC [62], CDK2, CDC7, and CDT1 [61]. Trichostatin A is a histone deacetylase (HDAC) inhibitor that is able to halt the cell cycle, induce apoptosis, and cease metastasis [61]. While Trichostatin A was found to successfully alter expression of MCMs along with other 30 genes responsible for cell cycle control, it has been shown to be highly toxic [61]. Genistein, on the other hand, is a naturally occurring nontoxic isoflavone. It also shows promise as an inhibitor of cancer cell proliferation, but at a relatively high dose of $50 \mu \mathrm{M}$ in vitro [61].

Widdrol is a sesquiterpene extracted from the Juniperus chinensis (Chinese Juniper) plant and commonly used in folk remedies to treat inflammation. Widdrol inhibits proliferation of cancer cells by affecting multiple signaling pathways, most notable decreasing the expression of CDK2 and its partner cyclin E, while increasing the expression of its inhibitor p21 [63]. Downstream of these events, Widdrol leads to a downregulation of expression of the MCM proteins [63].

Metformin is a biguanide that is approved for the management of type 2 diabetes. Aside from controlling the blood glucose levels, Metformin displayed anti-proliferative effects on cancer cells [64]. It was shown that Metformin targets the AMPK and NF-kB pathways with consecutive downregulation of expression of dozens genes involved in mitosis and DNA replication, including expression of the MCM proteins [64].

Bromodomain and Extra-Terminal inhibitors (BETi) act on bromodomain and extra-terminal of BET proteins, decreasing proliferation and inducing apoptosis of cancer cells [65]. Among many other targets, BETi were shown to downregulate MCM5 expression by affecting corresponding transcriptionregulating BET proteins [65]. 
Breviscapine, also known as scutellarin, is a naturally occurring flavone often extracted from the Chinese daisy Erigeron breviscapus. It is used medicinally against cardiovascular disease. In cancer research, it was shown to have a cytotoxic and proapoptotic effect on prostate cancer cells as well as an inhibitory effect on expression of MCM7 [66].

Heliquinomycin is a Streptomyces derived antibiotic that was shown to inhibit cellular proliferation, DNA unwinding, and ATP-ase activity of human MCM 4/6/7 complex [67]. Based on administered dosage, it also inhibited DNA polymerase, DNA primase, and - to a lesser degree - other studied helicases, indicating that Heliquinomycin may affect a variety of DNA-associated enzymes. As MCM4/6/7 complex represents an artificial helicase composed of only MCM4, MCM6, and MCM7 subunits, it would be important to test this compound with a fully-assembled CMG helicase. In support of the helicase reserve model, Heliquinomycin displayed much higher inhibitory activity toward A549 and SBC5 lung cancer cells and SW780 bladder cancer cells, as compared to normal HLF-1 cells [59].

Ciprofloxacin is a fluoroquinolone and, like heliquinomycin, has an antibiotic activity. In in vitro studies, ciprofloxacin was shown to have similar inhibitory effects on MCM2-7 and MCM4/6/7 complexes as well as viral SV40 helicase [68]. A separate study revealed that Ciprofloxacin directly intercalates with DNA [69], implicating that its inhibition may be due to a disturbance of the DNA structure, but not a direct effect on the helicase. Consistent with this mechanism, other DNA-associated enzymes, specifically topoisomerases, are known to be inhibited by fluoroquinolones [70]. Because during DNA replication topoisomerases progress in front of helicases and replicative machinery, it is topoisomerase activity that must be the most affected by the present of Ciprofloxacin. Indeed, all cases of Ciprofloxacin-induced cytotoxicity toward cancer cells are attributed to the inhibition of type 2 DNA topoisomerases [71].

Conflict of interest. Authors have completed the Unified Conflicts of Interest form at http://ukrbiochemjournal.org/wp-content/uploads/2018/12/ coi_disclosure.pdf and declare no conflict of interest.

\section{РЕПЛІКАТИВНА СМG-ГЕЛІКАЗА: ІДЕАЛЬНА МІШЕНЬ ДЛЯ ТАРГЕТНОÏ ТЕРАПIÏ РАКУ}

\author{
W. Henderson, K. Nyman, M. Stoney, \\ S. I. Borysov \\ College of Arts and Sciences, Saint Leo \\ University, St. Leo, Florida, USA; \\ 凶e-mail: Sergiy.Borysov@saintleo.edu
}

Огляд присвячено Cdc45-Mcm2-7-GINS (CMG) геліказі, яка $€$ важливою складовою реплікативного механізму i розглядається як нова перспективна мішень для таргетної терапії раку. У нормальних клітинах під час реплікації геному поступово, шляхом залучення необхідної кількості субодиниць, активується лише невелика частина геліказ, решта складають значний пул сплячих геліказ та можуть бути активовані у разі необхідності для заміщення геліказ із пригніченою активністю, завдяки чому нормальна клітина має стійкість до інгібіторів геліказ. Відомо, що на відміну від нормальних клітин ракові клітини мають значно менший пул сплячих геліказ і через це мають бути вразливішими до інгібіторів CMG-геліказ. Функціональні дослідження підтверджують, що таргетне пригнічення CMG-гелікази може стати специфічним терапевтичним підходом у подоланні широкого спектра онкологічних захворювань та у мінімізації побічних ефектів. Передбачається, що препарати спрямованої дії на CMG-геліказу можуть використовуватися не тільки для самостійної терапії, а й як хіміосенсибілізатори в поєднанні 3 іншими ліками для підвищення їх клінічного ефекту.

Ключов і слова: ракові клітини, реплікативна CMG-геліказа, сплячі гелікази, інгібітори гелікази.

\section{References}

1. Cancer statistics. World Health Organization. Regime of access : https://www.who.int/newsroom/fact-sheets/detail/cancer (accessed, May, 2020).

2. Worldwide cancer statistics. Cancer Research UK. 2015. Regime of access : https://www. cancerresearchuk.org/health-professional/ cancer-statistics/worldwide-cancer (accessed, May, 2020). 
3. Global cancer facts \& figures. American Cancer Society. Regime of access : https://www.cancer. org/research/cancer-facts-statistics/global.html (accessed, May, 2020).

4. Stewart BW and Wild CW. World cancer report. 2014; Lyon: IARC Press.

5. The global cancer burden. American Cancer Society. Regime of access : https://www.cancer. org/health-care-professionals/our-global-healthwork/global-cancer-burden.html (accessed, May, 2020).

6. Cancer Treatments, 2019; Cancer Quest. Regime of access : http://www.cancerquest.org/patients/ treatments (accessed, October, 2019).

7. Radiation therapy. National Cancer Institute. 2015. Regime of access : https://www.cancer. gov/about-cancer/treatment/types/radationtherapy (accessed, September, 2019).

8. Chemotherapy. Cancer Quest. Regime of access : https://www.cancerquest.org/patients/ treatments/chemotherapy (accessed, September, 2019).

9. How chemotherapy works. Cancer Research UK. Regime of access : https://www. cancerresearchuk.org/about-cancer/cancerin-general/treatment/chemotherapy/howchemotherapy-works (accessed, September, 2019).

10. Farkona S, Diamandis EP, Blasutig IM. Cancer immunotherapy: the beginning of the end of cancer? BMC Med. 2016; 14(1): 73.

11. Siddiqui K, On KF, Diffley JFX. Regulating DNA replication in eukarya. Cold Spring Harb Perspect Biol. 2013; 5(9): a012930.

12. Puigvert JC, Sanjiv K, Helleday T. Targeting DNA repair, DNA metabolism and replication stress as anti-cancer strategies. FEBS J. 2016; 283(2): 232-245.

13. Bochman ML. Roles of DNA helicases in the maintenance of genome integrity. Mol Cell Oncol. 2014; 1(3): e963429.

14. Maine GT, Sinha P, Tye BK. Mutants of $S$. cerevisiae defective in the maintenance of minichromosomes. Genetics. 1984; 106(3): 365385.

15. Gómez EB, Catlett MG, Forsburg SL. Different phenotypes in vivo are associated with ATPase motif mutations in Schizosaccharomyces pombe minichromosome maintenance proteins. Genetics. 2002; 160(4): 1305-1318.

16. Davey MJ, Indiani C, O'Donnell $\mathrm{M}$. Reconstitution of the Mcm2-7p heterohexamer, subunit arrangement, and ATP site architecture. J Biol Chem. 2003; 278(7): 4491-4499.

17. Miller JM, Arachea BT, Epling LB, Enemark EJ. Analysis of the crystal structure of an active MCM hexamer. Elife. 2014; 3: e03433.

18. Ilves I, Petojevic T, Pesavento JJ, Botchan MR. Activation of the MCM2-7 helicase by association with Cdc45 and GINS proteins. Mol Cell. 2010; 37(2): 247-258.

19. Kang YH, Galal WC, Farina A, Tappin I, Hurwitz J. Properties of the human Cdc45/ Mcm2-7/GINS helicase complex and its action with DNA polymerase epsilon in rolling circle DNA synthesis. Proc Natl Acad Sci USA. 2012; 109(16): 6042-6047.

20. Aladjem MI. Replication in context: dynamic regulation of DNA replication patterns in metazoans. Nat Rev Genet. 2007; 8(8): 588-600.

21. Jatikusumo VA. Treslin and its role in the assembly of the replicative DNA helicase (Doctoral thesis). University of Cambridge. 2020. https://doi.org/10.17863/CAM.48462.

22. Wong PG, Winter SL, Zaika E, Cao TV, Oguz U, Koomen JM, Hamlin JL, Alexandrow MG. Cdc45 limits replicon usage from a low density of preRCs in mammalian cells. PLoS One. 2011; 6(3): e17533.

23. Pollok S, Bauerschmidt C, Sänger J, Nasheuer HP, Grosse F. Human Cdc45 is a proliferationassociated antigen. FEBS J. 2007; 274(14): 36693684.

24. Kamada K. The GINS complex: structure and function. Subcell Biochem. 2012; 62: 135-156.

25. Chang YP, Wang G, Bermudez V, Hurwitz J, Chen XS. Crystal structure of the GINS complex and functional insights into its role in DNA replication. Proc Natl Acad Sci USA. 2007; 104(31): 12685-12690.

26. Kamada K, Kubota Y, Arata T, Shindo Y, Hanaoka F. Structure of the human GINS complex and its assembly and functional interface in replication initiation. Nat Struct Mol Biol. 2007; 14(5): 388-396.

27. Choi JM, Lim HL, Kim JJ, Song OK, Cho Y. Crystal structure of the human GINS complex. Genes Dev. 2007; 21(11): 1316-1321.

28. Takayama Y, Kamimura Y, Okawa M, Muramatsu S, Sugino A, Araki H. GINS, a novel multiprotein complex required for chromosomal DNA replication in budding yeast. Genes Dev. 2003; 17(9): 1153-1165. 
29. Boskovic J, Coloma J, Aparicio T, Zhou M, Robinson CV, Méndez J, Montoya G. Molecular architecture of the human GINS complex. EMBO Rep. 2007; 8(7): 678-684.

30. MacNeill SA. Structure and function of the GINS complex, a key component of the eukaryotic replisome. Biochem J. 2010; 425(3): 489-500.

31. Makarova KS, Koonin EV, Kelman Z. The CMG (CDC45/RecJ, MCM, GINS) complex is a conserved component of the DNA replication system in all archaea and eukaryotes. Biol Direct. 2012; 7: 7.

32. Noguchi Y, Yuan Z, Bai L, Schneider S, Zhao G, Stillman B, Speck C, Li H. Cryo-EM structure of Mcm2-7 double hexamer on DNA suggests a lagging-strand DNA extrusion model. Proc Natl Acad Sci USA. 2017; 114(45): E9529-E9538.

33. Yuan Z, Bai L, Sun J, Georgescu R, Liu J, O'Donnell ME, Li H. Structure of the eukaryotic replicative CMG helicase suggests a pumpjack motion for translocation. Nat Struct Mol Biol. 2016; 23(3): 217-224.

34. Langston L, O'Donnell M. Action of CMG with strand-specific DNA blocks supports an internal unwinding mode for the eukaryotic replicative helicase. Elife. 2017; 6: e23449.

35. Georgescu R, Yuan Z, Bai L, de Luna Almeida Santos R, Sun J, Zhang D, Yurieva O, Li H, O'Donnell ME. Structure of eukaryotic CMG helicase at a replication fork and implications to replisome architecture and origin initiation. Proc Natl Acad Sci USA. 2017; 114(5): E697-E706.

36. Yuan Z, Georgescu R, Bai L, Zhang D, Li H, O'Donnell ME. DNA unwinding mechanism of a eukaryotic replicative CMG helicase. Nat Commun. 2020; 11(1): 688.

37. Riera A, Barbon M, Noguch Y, Reuter LM, Schneider S, Speck C. From structure to mechanism-understanding initiation of DNA replication. Genes Dev. 2017; 31(11): 1073-1088.

38. Klemm RD, Austin RJ, Bell SP. Coordinate binding of ATP and origin DNA regulates the ATPase activity of the origin recognition complex. Cell. 1997; 88(4): 493-502.

39. Liu J, Smith CL, DeRyckere D, DeAngelis K, Martin GS, Berger JM. Structure and function of Cdc6/Cdc18: implications for origin recognition and checkpoint control. Mol Cell. 2000; 6(3): 637-648.

40 Bell SP, Kaguni JM. Helicase loading at chromosomal origins of replication. Cold Spring Harb Perspect Biol. 2013; 5(6): a010124.
41. Bochman ML, Schwacha A. The Mcm2-7 complex has in vitro helicase activity. Mol Cell. 2008; 31(2): 287-293.

42. Costa A, Ilves I, Tamberg N, Petojevic T, Nogales E, Botchan MR, Berger JM. The structural basis for MCM2-7 helicase activation by GINS and Cdc45. Nat Struct Mol Biol. 2011; 18(4): 471-477.

43. Randell JCW, Bowers JL, Rodríguez HK, Bell SP. Sequential ATP hydrolysis by Cdc6 and ORC directs loading of the Mcm2-7 helicase. Mol Cell. 2006; 21(1): 29-39.

44. Evrin C, Clarke P, Zech J, Rudi L, Sun J, Uhle S, Li H, Stillman B, Speck C. A double-hexameric MCM2-7 complex is loaded onto origin DNA during licensing of eukaryotic DNA replication. Proc Natl Acad Sci USA. 2009; 106(48): 2024020245.

45. Shima N, Pederson KD. Dormant origins as a built-in safeguard in eukaryotic DNA replication against genome instability and disease development. DNA Repair (Amst). 2017; 56: 166-173.

46. Blow JJ, Ge XQ, Jackson DA. How dormant origins promote complete genome replication. Trends Biochem Sci. 2011; 36(8): 405-414.

47. Ilves I, Petojevic T, Pesavento JJ, Botchan MR. Activation of the MCM2-7 helicase by association with Cdc45 and GINS proteins. $\mathrm{Mol}$ Cell. 2010; 37(2): 247-258.

48. Tognetti S, Riera A, Speck C. Switch on the engine: how the eukaryotic replicative helicase MCM2-7 becomes activated. Chromosoma. 2015; 124(1): 13-26.

49. Dewar JM, Budzowska M, Walter JC. The mechanism of DNA replication termination in vertebrates. Nature. 2015; 525(7569): 345-350.

50. Moreno SP, Bailey R, Campion N, Herron S, Gambus A. Polyubiquitylation drives replisome disassembly at the termination of DNA replication. Science. 2014; 346(6208): 477-481.

51. Deegan TD, Mukherjee PP, Fujisawa R, Rivera CP, Labib K. CMG helicase disassembly is controlled by replication fork DNA, replisome components and a ubiquitin threshold. Elife. 2020; 9: e60371.

52. Woodward AM, Göhler T, Luciani MG, Oehlmann M, Ge X, Gartner A, Jackson DA, Blow JJ. Excess Mcm2-7 license dormant origins of replication that can be used under conditions of replicative stress. J Cell Biol. 2006; 173(5): 673-683. 
53. Ge XQ, Jackson DA, Blow JJ. Dormant origins licensed by excess Mcm2-7 are required for human cells to survive replicative stress. Genes Dev. 2007; 21(24): 3331-3341.

54. Ibarra A, Schwob E, Méndez J. Excess MCM proteins protect human cells from replicative stress by licensing backup origins of replication. Proc Natl Acad Sci USA. 2008; 105(26): 89568961.

55. Kawabata T, Luebben SW, Yamaguchi S, Ilves I, Matise I, Buske T, Botchan MR, Shima N. Stalled fork rescue via dormant replication origins in unchallenged $\mathrm{S}$ phase promotes proper chromosome segregation and tumor suppression. Mol Cell. 2011; 41(5): 543-553.

56. Shreeram S, Sparks A, Lane DP, Blow JJ. Cell type-specific responses of human cells to inhibition of replication licensing. Oncogene. 2002; 21(43): 6624-6632.

57. Lau E, Chiang GG, Abraham RT, Jiang W. Divergent $\mathrm{S}$ phase checkpoint activation arising from prereplicative complex deficiency controls cell survival. Mol Biol Cell. 2009; 20(17): 39533964.

58. Zimmerman KM, Jones RM, Petermann E, Jeggo PA. Diminished origin-licensing capacity specifically sensitizes tumor cells to replication stress. Mol Cancer Res. 2013; 11(4): 370-380.

59. Toyokawa G, Masuda K, Daigo Y, Cho HS, Yoshimatsu M, Takawa M, Hayami S, Maejima K, Chino M, Field HI, Neal DE, Tsuchiya Eiju , Ponder BAJ, Maehara Y, Nakamura Y, Hamamoto R. Minichromosome Maintenance Protein 7 is a potential therapeutic target in human cancer and a novel prognostic marker of non-small cell lung cancer. $\mathrm{Mol}$ Cancer. 2011; 10: 65.

60. Bryant VL, Elias RM, McCarthy SM, Yeatman TJ, Alexandrow MG. Suppression of Reserve MCM Complexes Chemosensitizes to Gemcitabine and 5-Fluorouracil. Mol Cancer Res. 2015; 13(9): 1296-1305.

61. Majid S, Dar AA, Saini S, Chen Y, Shahryari V, Liu J, Zaman MS, Hirata H, Yamamura S, Ueno K, Tanaka Y, Dahiya R. Regulation of minichromosome maintenance gene family by microRNA-1296 and genistein in prostate cancer. Cancer Res. 2010; 70(7): 2809-2818.
62. Liu Y, He G, Wang Y, Guan X, Pang X, Zhang B. MCM-2 is a therapeutic target of Trichostatin A in colon cancer cells. Toxicol Lett. 2013; 221(1): 23-30.

63. Kwon HJ, Hong YK, Park C, Choi YH, Yun HJ, Lee EW, Kim BW. Widdrol induces cell cycle arrest, associated with MCM down-regulation, in human colon adenocarcinoma cells. Cancer Lett. 2010; 290(1): 96-103.

64. Kim SH, Kim SC, Ku JL. Metformin increases chemo-sensitivity via gene downregulation encoding DNA replication proteins in 5-Fu resistant colorectal cancer cells. Oncotarget. 2017; 8(34): 56546-56557.

65. Mio C, Lavarone E, Conzatti K, Baldan F, Toffoletto B, Puppin C, Filetti S, Durante C, Russo D, Orlacchio A, Di Cristofano A, Di Loreto C, Damante G. MCM5 as a target of BET inhibitors in thyroid cancer cells. Endocr Relat Cancer. 2016; 23(4): 335-347.

66. Guan YB, Yang DR, Nong SJ, Ni J, Hu CH, Li J, Zhu J, Shan YX. Breviscapine (BVP) inhibits prostate cancer progression through damaging DNA by minichromosome maintenance protein-7 (MCM-7) modulation. Biomed Pharmacother. 2017; 93: 103-116.

67. Ishimi Y, Sugiyama T, Nakaya R, Kanamori M, Kohno T, Enomoto T, Chino M. Effect of heliquinomycin on the activity of human minichromosome maintenance 4/6/7 helicase. FEBS J. 2009; 276(12): 3382-3391.

68. Simon N, Bochman ML, Seguin S, Brodsky JL, Seibel WL, Schwacha A. Ciprofloxacin is an inhibitor of the Mcm2-7 replicative helicase. Biosci Rep. 2013; 33(5): e00072.

69. Shahabadi N, Asadian AA, Mahdavi M. Intercalation of a $\mathrm{Zn}(\mathrm{II})$ complex containing ciprofloxacin drug between DNA base pairs. Nucleosides Nucleotides Nucleic Acids. 2017; 36(11): 676-689.

70. Majalekar PP, Shirote PJ. Fluoroquinolones: Blessings Or Curses. Curr Drug Targets. 2020; 21(13): 1354-1370.

71. Abdel-Aal MAA, Abdel-Aziz SA, Shaykoon MSA, Abuo-Rahma GEDA. Towards anticancer fluoroquinolones: A review article. Arch Pharm (Weinheim). 2019; 352(7): e1800376. 